\title{
PORÓWNANIE PARAMETRÓW WZROSTOWYCH I PRZYDATNOŚCI HODOWLANEJ JEDNOROCZNYCH SADZONEK BUKA ZWYCZAJNEGO (FAGUS SYLVATICA L.)
}

\author{
Jacek Banach*, Kinga Skrzyszewska, Kinga Blachlińska
}

Katedra Ekologii i Hodowli Lasu, Wydział Leśny,

Uniwersytet Rolniczy im. Hugona Kołłątaja w Krakowie, al. 29 Listopada 46, 31-425 Kraków

\section{ABSTRAKT}

Celem badań było porównanie parametrów wzrostowych oraz wskaźników oceny przydatności hodowlanej sadzonek w zależności od ich klasy jakości, którą określono na podstawie wymagań zawartych w polskiej normie PN-R-67025 (1999). Materiałem badawczym były sadzonki buka zwyczajnego wyhodowane w warunkach kontrolowanych, które rozdzielono na trzy klasy jakości (I, II, pozaklasowe). Sadzonki należące do poszczególnych klas istotnie różniły się parametrami wzrostowymi, z wyjątkiem długości systemu korzeniowego, a najwyższe wartości charakteryzowały I klasę jakości. Wskaźniki oceny przydatności hodowlanej nie potwierdziły w pełni tej reguły. Średnia wartość indeksu jakości Dicksona (DQI) wskazała, że najbardziej przydatne do posadzenia na uprawie będą sadzonki I klasy, jednak dla współczynnika wytrzymałości (SQ) nie otrzymano istotnej różnicy, a najlepszym współczynnikiem pędowo-korzeniowym (S/R) charakteryzowały się sadzonki pozaklasowe. Uzyskane wyniki wskazują, że część sadzonek pozaklasowych może być wykorzystana do posadzenia na uprawie pomimo niespełnienia minimalnych wartości cech wzrostowych zawartych w normie PN-R-67025 stosowanej w Lasach Państwowych. Nasze badania sugerują również, że do oceny jakości materiału sadzeniowego jako element uzupełniający klasyfikację wymiarową można włączyć wskaźniki przydatności hodowlanej (SQ, S/R, DQI).

\footnotetext{
* $\bowtie$ jacek.banach@urk.edu.pl
} 


\section{SŁOWA KLUCZOWE}

norma PN-R-67025, WinRhizo, przydatność hodowlana, współczynnik wytrzymałości, współczynnik pędowo-korzeniowy, indeks jakości Dicksona

\section{ABSTRACT}

The aim of the study was to compare the growth parameters and the indicators of seedlings' breeding usefulness assessment depending on their quality class, which was determined on the basis of the requirements of the Polish standard PN-R-67025 (1999). The research material consisted of European beech seedlings grown in controlled conditions, which were divided into three quality classes ("class I", "class II", and "classless"). The seedlings belonging to individual classes differed significantly in their growth parameters, with the exception of the length of the root system, and the highest values were characteristic of quality class I. The breeding usefulness assessment indicators did not fully confirm this rule. The average value of the Dickson quality index (DQI) indicated that class I seedlings would be the most suitable for planting, but for the sturdiness quotient (SQ) no significant difference was obtained, and the classless seedlings had the best root-shoot ratio $(\mathrm{S} / \mathrm{R})$. The obtained results indicate that some classless seedlings can be used for planting in a forest plantation despite the failure to meet the minimum values of growth traits contained in the PN-R-67025 standard used by the State Forests. Our research also suggests that in the assessment of the quality of planting material, as an element complementing the dimensional classification, we can include indicators of breeding suitability (SQ, S/R, and DQI).

\section{KEYWORDS}

PN-R-67025 standard, WinRhizo, breeding suitability, sturdiness quotient, stem-root ratio, Dickson quality index

\section{Wstęp}

Jakość sadzonek wpływa znacząco na udatność upraw leśnych. Stosowana w Lasach Państwowych norma PN-R-67025 (1999) do klasyfikacji sadzonek bazuje na ich parametrach wzrostowych, tj. wysokości, długości systemu korzeniowego oraz grubości w szyjce korzeniowej. W normie przyjęto zasadę, że im większe parametry sadzonki, tym wyższa jest klasa jakości przy zachowaniu proporcjonalności części nadziemnej do systemu korzeniowego. Badania prowadzone przez różnych autorów wykazują, że nie w każdym przypadku wysokie sadzonki dobrze adaptują się po posadzeniu na uprawie. Grossnickle (2012) podaje, że sadzonki wysokie dobrze zaadaptują się tylko w korzystnych warunkach środowiskowych, natomiast w niekorzystnych lepsze będą sadzonki niskie. Według tego autora ważniejsza od bezwzględnych wartości parametrów wzrostowych sadzonki jest np. proporcja masy jej części nadziemnej do masy systemu korzeniowego, czyli tzw. współczynnik pędowo-korzeniowy. Potwierdzają to wyniki badań innych autorów (Kozlowski i Pallardy 2002, del Campo i in. 2010, Ivetić 
i in. 2016). Istotnego wpływu wysokości początkowej sadzonek buka zwyczajnego na ich późniejszą reakcję przyrostową po posadzeniu na uprawie doświadczalnej dowodzą również wyniki uzyskane przez Banacha i in. (2020a).

Celem badań było porównanie parametrów wzrostowych oraz wskaźników przydatności hodowlanej sadzonek buka zwyczajnego w zależności od klasy ich jakości określonej na podstawie wymagań zawartych w normie PN-R-67025 (1999). Postawiono hipotezę, że sadzonki buka będą różniły się parametrami wzrostowymi, co jest konsekwencją zastosowanej klasyfikacji, ale nie będą różniły się wskaźnikami przydatności hodowlanej.

\section{Materiał i metody}

Sadzonki buka zwyczajnego zostały wyhodowane w szkółce doświadczalnej „Kopciowa” Stacji Dydaktyczno-Badawczej w Katedrze Ekologii i Hodowli Lasu jako komercyjna produkcja na potrzeby Leśnego Zakładu Doświadczalnego w Krynicy-Zdroju. Nasiona buka wysiano pod koniec kwietnia 2020 r. do świeżo przygotowanego podłoża trocinowo-torfowego (1:1), nawiezionego startowo nawozem Yara Mila Complex w dawce $2,5 \mathrm{~kg} \cdot \mathrm{m}^{-3}$, o składzie: azot całkowity $(\mathrm{N})-12 \%$ (w tym: $5 \%$ $\mathrm{N}-\mathrm{NO}_{3}$ i $\left.7 \% \mathrm{~N}-\mathrm{NH}_{4}\right)$; fosfor $\left(\mathrm{P}_{2} \mathrm{O}_{5}\right)-18,7 \%$; potas $\left(\mathrm{K}_{2} \mathrm{O}\right)-18 \%$; magnez $(\mathrm{MgO})-$ $2,7 \%$; siarka $\left(\mathrm{SO}_{3}\right)-20 \%$; bor $(\mathrm{B})-0,015 \%$; żelazo $(\mathrm{Fe})-0,20 \%$; mangan $(\mathrm{Mn})-$ $0,02 \%$; cynk $(\mathrm{Zn})-0,02 \%$. Podłoże umieszczono na grządce hodowlanej w namiocie foliowym. Sadzonki do oceny pobrano 30 września 2020 r. z 10 miejsc na grządce i oczyszczono systemy korzeniowe z podłoża. Sadzonki zostały ocenione według wymagań ogólnych zawartych w normie PN-R-67025 (1999), a następnie pomierzone i posortowane na trzy grupy (klasa I, klasa II, pozaklasowe) na podstawie wartości wysokości (pomiar z dokładnością do 0,1 cm), długości systemu korzeniowego $(0,1 \mathrm{~cm})$ i grubości w szyjce korzeniowej $(0,1 \mathrm{~mm})$. Każda klasa jakości była reprezentowana przez 60 sadzonek, które oznakowano etykietami z numerem w celu umożliwienia ich identyfikacji w dalszych etapach analizy.

Po przeprowadzeniu czynności pomiarowo-klasyfikacyjnych korzenie zostały dokładnie oczyszczone $z$ resztek podłoża i umyte. Każdą sadzonkę umieszczono na zanumerowanej tekturowej tacce, równocześnie oddzielono jej liście i przecięto w szyjce korzeniowej. Pęd i system korzeniowy każdej sadzonki zostały zeskanowane (skaner Epson Photo V800), a uzyskane obrazy elektroniczne przeanalizowano w programie WinRhizo (Regent Software Inc.). W kolejnym etapie badania rośliny umieszczono w suszarce laboratoryjnej, gdzie były suszone przez 72 godziny w temperaturze $65^{\circ} \mathrm{C}$, a po wystudzeniu zważono każdą ich część z dokładnością do 0,001 g.

Analizą objęto następujące cechy wzrostowe sadzonek: wysokość sadzonki, długość systemu korzeniowego, średnicę w szyjce korzeniowej, długość, objętość oraz przeciętną średnicę korzeni i pędów, a także sumaryczną długość korzeni drobnych (o średnicy $\leq 2 \mathrm{~mm}$ ) oraz korzeni szkieletowych (>2 mm). Wykorzystując wyniki pomiarów, obliczono trzy wskaźniki syntetyczne określające przydatność hodowlaną sadzonek, tj. 
współczynnik wytrzymałości sadzonki - SQ, współczynnik pędowo-korzeniowy - S/R, a także indeks jakości Dicksona - DQI (Banach i in. 2020b). Wartość współczynnika SQ, liczonego jako iloraz wysokości sadzonki do jej średnicy w szyjce korzeniowej, wskazuje na odporność sadzonek na niekorzystne czynniki abiotyczne. Sadzonki z niskim SQ charakteryzują się wyższą odpornością oraz lepszą przeżywalnością od tych, które osiągają wysokie wartości współczynnika. Maksymalna wartość SQ dla buka zwyczajnego wynosi 65 (Banach i in. 2020b). Współczynnik pędowo-korzeniowy (S/R) liczony jest jako stosunek suchej masy pędu wraz z aparatem asymilacyjnym do suchej masy systemu korzeniowego; określa on proporcję między powierzchnią transpiracyjną a powierzchnią pochłaniania, dla sadzonek wyhodowanych w gruncie powinien wynosić nie więcej niż 3:1, a dla sadzonek ze sztucznego podłoża - 2:1 (Thompson 1985, Haase 2007). Indeks jakości Dicksona (DQI) obliczany jest jako proporcja suchej masy sadzonki do sumy współczynników SQ i S/R. DQI wyznacza zdolności sadzonki do zaadaptowania się po posadzeniu na uprawie, a im wyższa jest jego wartość, tym szanse na prawidłowe zaaklimatyzowanie rośliny są większe (Dickson i in. 1960).

W celu stwierdzenia istotności różnic między sadzonkami zakwalifikowanymi do poszczególnych klas jakości dane pomiarowe dla wszystkich cech zostały poddane analizie wariancji w programie TIBCO Statistica 13.3 (2017), a dla uzyskanych wartości średnich wyliczono także grupy jednorodne testem Tukey’a $(p=0,05)$. Obliczono udział sadzonek spełniających i niespełniających kryterium $S Q \leq 65$ oraz $S / R \leq 2: 1$ oraz sprawdzono testem $\chi^{2}$ Pearsona istotność różnic między wyliczonymi frakcjami.

\section{Wyniki}

\section{Cechy wzrostowe}

Średnie wartości wysokości i grubości w szyjce korzeniowej sadzonek buka zwyczajnego według normy PN-R-67025 (1999) wynosiły odpowiednio w klasie I - 32,5 cm i $6,3 \mathrm{~mm}$, następnie w klasie II - 24,1 cm i 5,0 mm, najniższe wartości miały sadzonki pozaklasowe - 16,9 cm i 3,4 mm. Dla tych cech uzyskano statystycznie istotną różnicę między wartościami średnimi, każda z nich znalazła się w innej grupie jednorodnej. W przypadku długości systemu korzeniowego nie wykazano statystycznej różnicy między wartościami średnimi dla wyróżnionych klas jakości. Sucha masa całej sadzonki oraz poszczególnych jej części, tj. systemu korzeniowego, pędu oraz liści w trzech klasach jakości, różniła się istotnie i każda wartość średnia dla cechy tworzyła odrębną grupę jednorodną. Sucha masa sadzonek z klasy I była prawie dwa razy większa niż sadzonek z klasy II oraz o ponad cztery razy większa od sklasyfikowanych jako pozaklasowe (tab. 1). 
Tabela 1. Średnie wartości ( \pm SE) cech wzrostowych sadzonek buka zwyczajnego w klasach jakości wyróżnionych według polskiej normy PN-R-67025 (a-c - grupy jednorodne określone testem Tukey'a, $p<0,05$ )

Table 1. Average values ( \pm SE) of growth traits of European beech seedlings in quality classes distinguished according to the Polish standard PN-R-67025 ( $\mathrm{a}-\mathrm{c}-$ homogeneous groups determined by Tukey's test, $p<0.05$ )

\begin{tabular}{|c|c|c|c|}
\hline \multirow[b]{2}{*}{ Cecha / Trait } & \multicolumn{3}{|c|}{ Klasa jakości sadzonki / Seedling quality class } \\
\hline & I & II & $\begin{array}{l}\text { pozaklasowe } \\
\text { classless }\end{array}$ \\
\hline $\begin{array}{l}\text { Wysokość sadzonki }(\mathrm{cm}) \\
\text { Seedling height }(\mathrm{cm})\end{array}$ & $32,5 \pm 0,7^{a}$ & $24,1 \pm 0,4^{b}$ & $16,9 \pm 0,3^{c}$ \\
\hline $\begin{array}{l}\text { Długość systemu korzeniowego }(\mathrm{cm}) \\
\text { Length of the root system }(\mathrm{cm})\end{array}$ & $30,6 \pm 0,9^{a}$ & $28,0 \pm 1,1^{a}$ & $29,7 \pm 1,2^{\mathrm{a}}$ \\
\hline $\begin{array}{l}\text { Srednica w szyjce korzeniowej }(\mathrm{mm}) \\
\text { Root collar diameter }(\mathrm{mm})\end{array}$ & $6,3 \pm 0,2^{\mathrm{a}}$ & $5,0 \pm 0,2^{b}$ & $3,4 \pm 0,1^{c}$ \\
\hline $\begin{array}{l}\text { Sucha masa sadzonki }(\mathrm{g}) \\
\text { Total seedling dry weight }(\mathrm{g})\end{array}$ & $5,871 \pm 0,366^{a}$ & $2,990 \pm 0,182^{b}$ & $1,235 \pm 0,084^{c}$ \\
\hline $\begin{array}{l}\text { Sucha masa pędów (g) } \\
\text { Stem dry weight }(\mathrm{g})\end{array}$ & $2,253 \pm 0,144^{a}$ & $1,088 \pm 0,072^{b}$ & $0,441 \pm 0,029^{c}$ \\
\hline $\begin{array}{l}\text { Sucha masa systemu korzeniowego (g) } \\
\text { Root system dry weight (g) }\end{array}$ & $2,355 \pm 0,169^{a}$ & $1,254 \pm 0,086^{b}$ & $0,542 \pm 0,041^{c}$ \\
\hline $\begin{array}{l}\text { Sucha masa liści (g) } \\
\text { Leaves dry weight (g) }\end{array}$ & $1,263 \pm 0,086^{a}$ & $0,648 \pm 0,041^{b}$ & $0,252 \pm 0,018^{c}$ \\
\hline
\end{tabular}

\section{System korzeniowy i pęd}

Analiza parametrów systemu korzeniowego i pędów wykazała statystycznie istotne zróżnicowanie między wartościami średnimi dla wyróżnionych klas (odrębne grupy jednorodne), z wyjątkiem przeciętnej średnicy korzeni oraz sumarycznej objętości korzeni, dla których nie stwierdzono różnicy między sadzonkami należącymi do klasy I i II, a wartości średnie znalazły się w tej samej grupie jednorodnej. W każdej klasie jakości dominowały korzenie drobne, tj. o średnicy $\leq 2 \mathrm{~mm}$ (ok. 97-98\%). Największą różnicę między wartościami średnimi dla każdej z klas jakości uzyskano w przypadku sumarycznej objętości pędów. Dla klasy I wartość tej cechy wyniosła $3,448 \mathrm{~cm}^{3}$, a dla sadzonek pozaklasowych $-0,858 \mathrm{~cm}^{3}$, czyli objętość pędów tych sadzonek była ponad cztery razy mniejsza (tab. 2). 
Tabela 2. Średnie wartości ( \pm SE) cech korzeni i pędów sadzonek buka zwyczajnego w klasach jakości wyróżnionych według polskiej normy PN-R-67025 (a-c - grupy jednorodne określone testem Tukey'a, $p<0,05)$

Table 2. Average values ( \pm SE) of the roots and shoots characteristics of European beech seedlings in quality classes distinguished according to the Polish standard PN-R-67025 (a-c - homogeneous groups determined by the Tukey's test, $p<0.05$ )

\begin{tabular}{|c|c|c|c|}
\hline \multirow[b]{2}{*}{ Cecha / Trait } & \multicolumn{3}{|c|}{ Klasa jakości sadzonki / Seedling quality class } \\
\hline & I & II & $\begin{array}{l}\text { pozaklasowe } \\
\text { classless }\end{array}$ \\
\hline $\begin{array}{l}\text { Sumaryczna długość korzeni }(\mathrm{cm}) \\
\text { Total length of the roots }(\mathrm{cm})\end{array}$ & $694,7 \pm 40,7^{a}$ & $574,7 \pm 31,2^{b}$ & $398,4 \pm 26,9^{c}$ \\
\hline $\begin{array}{l}\text { Przeciętna średnica korzeni }(\mathrm{mm}) \\
\text { Average diameter of the roots }(\mathrm{mm})\end{array}$ & $0,43 \pm 0,01^{a}$ & $0,45 \pm 0,01^{a}$ & $0,37 \pm 0,01^{\mathrm{b}}$ \\
\hline $\begin{array}{l}\text { Sumaryczna objętość korzeni }\left(\mathrm{cm}^{3}\right) \\
\text { Total volume of the roots }\left(\mathrm{cm}^{3}\right)\end{array}$ & $1,024 \pm 0,066^{\mathrm{a}}$ & $0,879 \pm 0,042^{a}$ & $0,424 \pm 0,030^{b}$ \\
\hline $\begin{array}{l}\text { Sumaryczna długość korzeni o średnicy } \\
\leq 2 \mathrm{~mm}(\mathrm{~cm}) \\
\text { Total length of the roots with a diameter } \\
\text { of } \leq 2 \mathrm{~mm}(\mathrm{~cm})\end{array}$ & $676,8 \pm 40,4^{\mathrm{a}}$ & $559,5 \pm 31,1^{b}$ & $389,7 \pm 26,7^{c}$ \\
\hline $\begin{array}{l}\text { Sumaryczna długość korzeni o średnicy } \\
>2 \mathrm{~mm}(\mathrm{~cm}) \\
\text { Total length of the roots with a diameter } \\
\text { of }>2 \mathrm{~mm}(\mathrm{~cm})\end{array}$ & $17,6 \pm 0,6^{\mathrm{a}}$ & $15,0 \pm 0,6^{b}$ & $8,5 \pm 0,4^{c}$ \\
\hline $\begin{array}{l}\text { Sumaryczna długość pędów }(\mathrm{cm}) \\
\text { Total length of the shoots }(\mathrm{cm})\end{array}$ & $66,7 \pm 3,1^{a}$ & $45,1 \pm 2,0^{b}$ & $28,5 \pm 1,1^{c}$ \\
\hline $\begin{array}{l}\text { Przeciętna średnica pędów }(\mathrm{mm}) \\
\text { Average diameter of the shoots }(\mathrm{mm})\end{array}$ & $2,54 \pm 0,04^{a}$ & $2,32 \pm 0,04^{\mathrm{b}}$ & $1,92 \pm 0,04^{c}$ \\
\hline $\begin{array}{l}\text { Sumaryczna objętość pędów }\left(\mathrm{cm}^{3}\right) \\
\text { Total volume of the shoots }\left(\mathrm{cm}^{3}\right)\end{array}$ & $3,448 \pm 0,188^{a}$ & $1,931 \pm 0,110^{b}$ & $0,858 \pm 0,053^{c}$ \\
\hline
\end{tabular}

\section{Współczynniki przydatności hodowlanej}

Przeciętny współczynnik wytrzymałości sadzonki (SQ), liczony jako proporcja wysokości i grubości w szyjce korzeniowej, wyniósł 53,9 dla klasy I, 51,4 dla klasy II, a dla sadzonek pozaklasowych - 51,7. Różnice między wartościami średnimi współczynnika dla buków w wyróżnionych klasach okazały się nieznaczne, a wszystkie wartości średnie tego współczynnika znalazły się w tej samej grupie jednorodnej. Przeanalizowano także dwa współczynniki uwzględniające parametry suchej masy, tj. indeks jakości 
Dicksona (DQI) oraz współczynnik pędowo-korzeniowy (S/R). Najwyższą wartość DQI osiągnęły sadzonki klasy I (0,933), co wskazuje, że to one mają największe szanse na prawidłowe zaadaptowanie się na uprawie, sadzonki klasy II i pozaklasowe miały wartości DQI proporcjonalnie niższe. W przypadku tego wskaźnika różnice dla sadzonek należących do poszczególnych klas jakości były statystycznie istotne. Podobnie było w przypadku indeksu S/R. Jego średnia wartość dla sadzonek klasy I była najgorsza, wynosząc 1,66, zdecydowanie lepszą proporcją charakteryzowały się sadzonki klasy II - 1,49, a najlepszą pozaklasowe - 1,40 (tab. 3).

Tabela 3. Średnie wartości ( \pm SE) wskaźników przydatności hodowlanej sadzonek buka zwyczajnego w klasach jakości wyróżnionych według polskiej normy PN-R-67025 (a-c grupy jednorodne określone testem Tukey’a, $p<0,05)$

Table 3. Average values $( \pm$ SE) of the breeding suitability indices of European beech seedlings in quality classes distinguished according to the Polish standard PN-R-67025 (a-c homogeneous groups determined by Tukey's test, $p<0.05$ )

\begin{tabular}{|l|c|c|c|}
\hline \multirow{2}{*}{\multicolumn{1}{|c|}{ Cecha / Trait }} & \multicolumn{2}{|c|}{ Klasa jakości sadzonki / Seedling quality class } \\
\cline { 2 - 4 } & I & II & $\begin{array}{c}\text { pozaklasowe } \\
\text { classless }\end{array}$ \\
\hline $\begin{array}{l}\text { Współczynnik wytrzymałości sadzonki (SQ) } \\
\text { Sturdiness quotient (SQ) }\end{array}$ & $53,9 \pm 1,8^{\text {a }}$ & $51,4 \pm 1,7^{\text {a }}$ & $51,7 \pm 1,3^{\text {a }}$ \\
\hline $\begin{array}{l}\text { Współczynnik pędowo-korzeniowy (S/R) } \\
\text { Stem-root ratio (S/R) }\end{array}$ & $1,66 \pm 0,08^{\mathrm{b}}$ & $1,49 \pm 0,06^{\mathrm{ab}}$ & $1,40 \pm 0,05^{\mathrm{a}}$ \\
\hline $\begin{array}{l}\text { Indeks jakości Dicksona (DQI) } \\
\text { Dickson quality index (DQI) }\end{array}$ & $0,933 \pm 0,075^{\mathrm{a}}$ & $0,511 \pm 0,043^{\mathrm{b}}$ & $0,208 \pm 0,018^{\mathrm{c}}$ \\
\hline
\end{tabular}

Udział sadzonek buka niespełniających kryterium maksymalnej wartości współczynnika wytrzymałości, tj. SQ $=65$, był taki sam dla klasy I i II $(18,3 \%)$, natomiast nieco mniejszy dla sadzonek pozaklasowych. Jednakże testem $\chi^{2}$ nie wykazano statystycznie istotnej różnicy między otrzymanymi frakcjami (ryc. 1). Dla współczynnika pędowo-korzeniowego frakcja sadzonek niespełniających kryterium $S / R \leq 2: 1$ była również najwyższa dla klasy I (18,3\%), natomiast dla klasy II i sadzonek pozaklasowych wynosiła po $13,3 \%$. Podobnie jak dla współczynnika SQ, wykonując test $\chi^{2}$, nie stwierdzono istotnych różnic między obliczonymi frakcjami sadzonek (ryc. 2). Największe zróżnicowanie indeksu jakości Dicksona otrzymano dla sadzonek zakwalifikowanych do I klasy jakości, natomiast najmniejszą jego wartość uzyskano dla sadzonek pozaklasowych. Wartości tego indeksu dla części sadzonek pozaklasowych (wartości odstające i ekstremalnie odstające) okazały się wyższe niż średnia dla sadzonek klasy II oraz dla części sadzonek zakwalifikowanych do I klasy jakości (ryc. 3). 


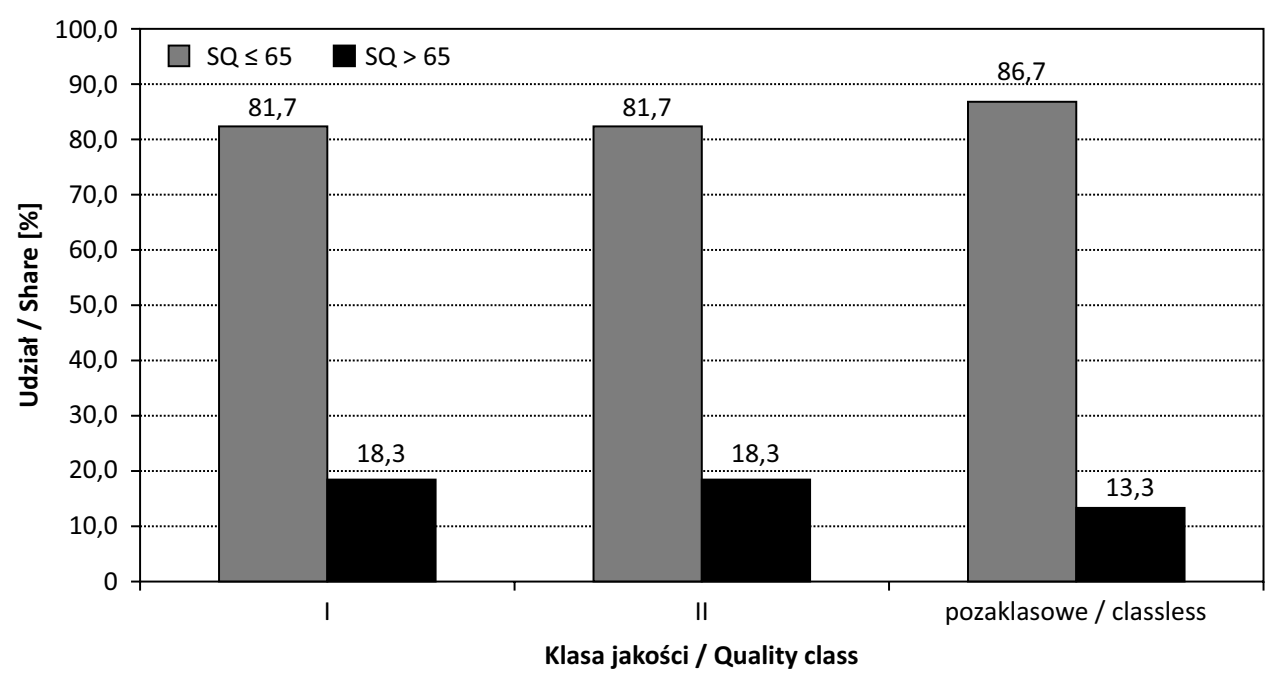

Ryc. 1. Udział sadzonek buka zwyczajnego w klasach jakości wyróżnionych według polskiej normy PN-R-67025 spełniających i niespełniających kryterium SQ $\leq 65(\chi 2=0,7200$, $p=0,698)$

Fig. 1. Share of European beech seedlings in quality classes distinguished according to the Polish standard PN-R-67025 that meet and do not meet the criterion SQ $\leq 65(\chi 2=0.7200$, $p=0.698)$

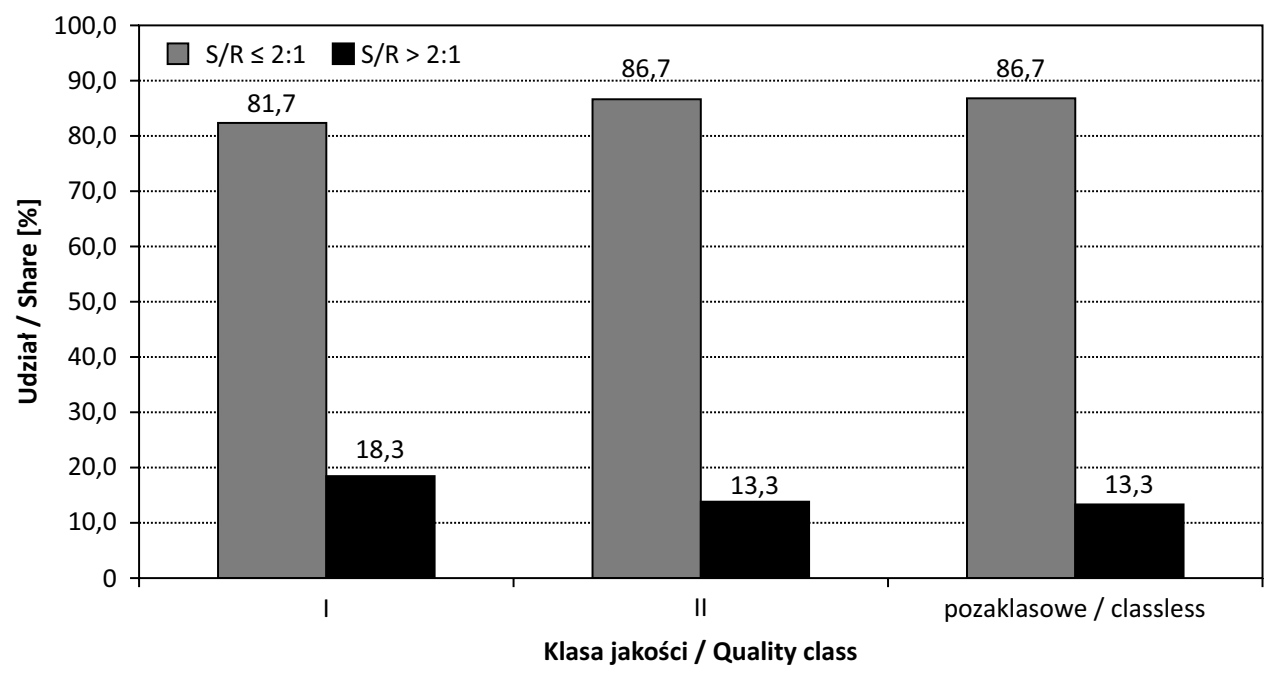

Ryc. 2. Udział sadzonek buka zwyczajnego w klasach jakości wyróżnionych według polskiej normy PN-R-67025 spełniających i niespełniających kryterium $S / R \leq 2: 1(\chi 2=0,7843$, $p=0,676)$

Fig. 2. Share of European beech seedlings in quality classes distinguished according to the Polish standard PN-R-67025 that meet and do not meet the criterion $\mathrm{S} / \mathrm{R} \leq 2: 1(\chi 2=0.7843$, $p=0.676)$ 


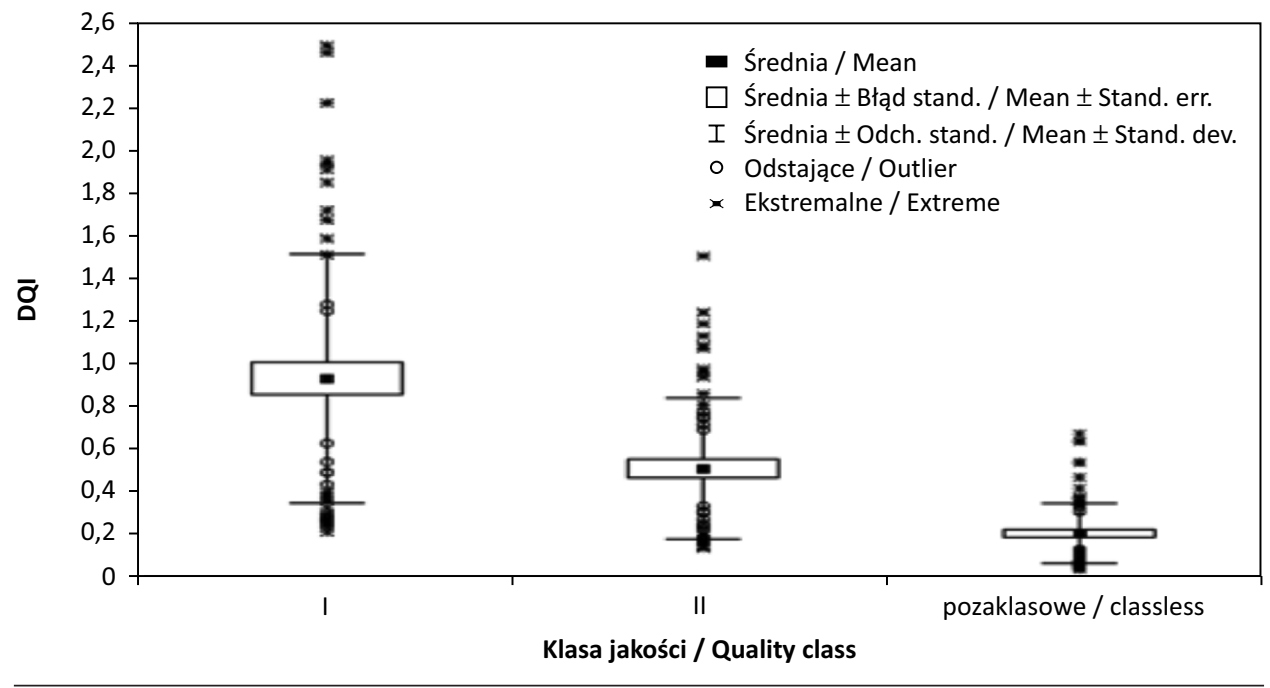

Ryc. 3. Zakres zróżnicowania indeksu jakości Dicksona (DQI) sadzonek buka zwyczajnego w klasach jakości wyróżnionych według polskiej normy PN-R-67025

Fig. 3. The range of variability of the Dickson quality index (DQI) of European beech seedlings in quality classes distinguished according to the Polish standard PN-R-67025

\section{Dyskusja}

Dwa parametry sadzonek spośród trzech uwzględnianych w klasyfikacji sadzonek według normy PN-R-67025 (1999), tj. wysokość i grubość w szyjce korzeniowej, różnicowały istotnie wyróżnione klasy jakości. Jedynie długość systemu korzeniowego okazała się cechą, która nie zależała od klasy jakości sadzonek. Taki rezultat sugeruje możliwość korekty zasad klasyfikacji sadzonek i ograniczenie znaczenia tego parametru. Cechy wzrostowe sadzonek są często używane do przewidywania adaptacji sadzonek na uprawie. Badania nad sosną kalifornijską i daglezją dowiodły, że prognozowanie wzrostu sadzonek po posadzeniu na podstawie ich wysokości, którą uzyskały na etapie hodowli w szkółce, okazało się mało przydatne. W tym przypadku lepszym wskaźnikiem jakości sadzonek była ich średnica w szyjce korzeniowej (Chavasse 1977). Potwierdziły to także badania Khanala i in. (2018), w których wykazano, że użycie sadzonek o większej średnicy zwiększało ich przeżywalność w pierwszym roku po posadzeniu na uprawie. Podobny efekt dało stosowanie sadzonek o dużej objętości korzeni i udziale korzeni drobnych oraz zwiększonej liczbie korzeni bocznych pierwszego rzędu, co skutkowało poprawą udatności (Davis i Jacobs 2005). Porównywalne wyniki uzyskano dla pięciu gatunków sadzonych na plantacjach drzew o krótkiej rotacji, zakładanych w Burkina Faso, potwierdzające przydatność średnicy w szyjce korzeniowej do przewidywania przeżywalności i wzrostu po posadzeniu w warunkach ograniczonej dostępności wody, jednak jeszcze lepszym wyznacznikiem okazał się indeks jakości Dicksona (Bayala i in. 2009). Konkluzja dotycząca większej przydatności 
różnych syntetycznych wskaźników jakościowych niż parametry wzrostowe sadzonek została także potwierdzona w innych badaniach (del Campo i in. 2010, Grossnickle 2012, Ivetić i in. 2016). Z cytowanych wcześniej badań wynika, że lepszym sposobem do przewidywania dobrej adaptacji sadzonek po posadzeniu na uprawie może być stosowanie różnych wskaźników syntetycznych, które oblicza się na bazie wielkości cech wzrostowych i suchej masy (Dickson i in. 1960, Thompson 1985, Haase 2007, Banach i in. 2020b). Na podstawie wartości wskaźników można prognozować przeżywalność i przyrost na wysokość w pierwszych latach wzrostu na uprawie. Pierwszym z nich jest współczynnik wytrzymałości (SQ), który decyduje o odporności sadzonki na czynniki abiotyczne, co z kolei przekłada się na jej przeżywalność. Z przeprowadzonych analiz wynika, że średnio najwyższą wartość współczynnika SQ miały sadzonki buka w I klasie jakości. Oznacza to, że osiągały dużą wysokość przy relatywnie mniejszej średnicy w szyjce korzeniowej. Jednak uzyskane różnice między klasami jakości nie były istotne statystycznie, a tylko ok. $18 \%$ sadzonek przekroczyła wartość maksymalną $(\mathrm{SQ}=65)$. Indeks jakości Dicksona ma $\mathrm{z}$ kolei wpływ na prawidłowe adaptowanie się sadzonek na uprawach. Wartość najwyższą uzyskały sadzonki klasy I, z dużą przewagą nad klasą II oraz sadzonkami pozaklasowymi, co potwierdzałoby przydatność klasyfikacji według normy PN-R-67025 (1999). Jednakże odwrotny wynik uzyskano dla współczynnika pędowo-korzeniowego (S/R). Najgorszą proporcję między powierzchnią transpiracyjną (pędy + liście) a powierzchnią pochłaniania (system korzeniowy) wykazały sadzonki klasy I, nieco lepszą klasy II, a najlepsze pod tym względem okazały się sadzonki pozaklasowe. Może to wynikać ze zbyt dużych rozmiarów części nadziemnej sadzonek w I klasie jakości (średnia wysokość 32,5 cm), a badania przeprowadzone przez Banacha i in. (2020a) wykazały, że optymalny zakres wysokości sadzonek buka zwyczajnego hodowanego w kontenerach Hiko wynosi $18-36 \mathrm{~cm}$. Średnia wysokość buków pozaklasowych wynosząca $16,5 \mathrm{~cm}$ sugeruje, że przynajmniej część tego materiału sadzeniowego może wykazać dobrą adaptację po posadzeniu na uprawie, szczególnie w niekorzystnych warunkach środowiskowych. Potwierdzają to wyniki badań dotyczących stosowania sadzonek sosny kanaryjskiej, w których dowiedziono, że przy niedostatecznym poziomie wilgotności gleby w początkowym okresie po założeniu uprawy wykorzystanie małych sadzonek może poprawić ich przeżycie (Oliet i in. 2019). Zbieżny wynik uzyskano również w innych badaniach, w których wykazano, że małe sadzonki, mające ponadto ograniczoną zawartość składników odżywczych, są lepiej przystosowane do niekorzystnych mikrosiedlisk pozbawionych pełnego dostępu do wody (Cortina i in. 2013). Przytoczone badania wskazują, że klasyfikacja oparta na bezwzględnych wymiarach materiału szkółkarskiego, która jest stosowana w klasyfikacji według normy PN-R-67025, nie w każdym przypadku będzie właściwa, a przede wszystkim charakteryzuje ją ograniczona przydatność do przewidywania wysokiej przeżywalności oraz reakcji przyrostowej po posadzeniu sadzonek na uprawie. 


\section{Wnioski}

- Posortowanie materiału szkółkarskiego według normy PN-R-67025 potwierdziło występowanie istotnej różnicy między wyróżnionymi klasami jakości dla dwóch cech wysokości i średnicy w szyjce korzeniowej. Brak takiej różnicy dla długości systemu korzeniowego dowodzi, że wskazany parametr ma mniejsze znaczenie przy ocenie jakości sadzonek buka zwyczajnego wyhodowanych w warunkach kontrolowanych.

- Współczynnik wytrzymałości (SQ) nie wykazał korelacji z oceną jakości sadzonek wykonaną według normy PN-R-67025, gdyż nie uzyskano istotnych różnic między sadzonkami w poszczególnych klasach jakości, w przeciwieństwie do wartości indeksu jakości Dicksona (DQI), które różniły się istotnie, a kolejność wartości średnich była zbieżna z cechami wzrostowymi.

- Najbardziej korzystną proporcję suchej masy części nadziemnej do masy systemu korzeniowego (współczynnik S/R) uzyskał materiał pozaklasowy, a niekorzystną sadzonki zakwalifikowane do I klasy jakości.

- Wyniki badań sugerują, że do oceny jakości materiału sadzeniowego jako element uzupełniający klasyfikację wymiarową można włączyć dwa wskaźniki przydatności hodowlanej (S/R, DQI).

\section{Źródło finansowania}

Prace sfinansowano z subwencji Ministerstwa Nauki i Szkolnictwa Wyższego dla Uniwersytetu Rolniczego im. Hugona Kołłątaja w Krakowie na rok 2020(SUB/040012/ D019).

\section{Literatura}

Banach J., Małek M., Kormanek M., Durło G. 2020a. Growth of Fagus sylvatica L. and Picea abies (L.) Karst. seedlings grown in Hiko containers in the first year after planting. Sustainability, 12, 7155. DOI:10.3390/su12177155.

Banach J., Kormanek M., Jaźwiński J. 2020b. Jakość sosny zwyczajnej, buka zwyczajnego i dębu szypułkowego wyhodowanych z siewu na glebie leśnej o różnym stopniu zagęszczenia. Leśne Prace Badawcze, 81 (4): 167-174. DOI: 10.2478/frp-2020-0020.

Bayala J., Dianda M., Wilson J., Ouedraogo S.J., Sanon K. 2009. Predicting field performance of five irrigated tree species using seedling quality assessment in Burkina Faso, West Africa. New Forests, 38(3): 309-322. DOI: 10.1007/s11056-009-9149-4.

del Campo A.D., Navarro R.M., Ceacero C.J. 2010. Seedling quality and field performance of commercial stocklots of containerized holm oak (Quercus ilex) in Mediterranean Spain: an approach for establishing a quality standard. New Forests, 39: 19-37.

Chavasse C.G.R. 1977. The significance of planting height as an indicator of subsequent seedling growth. New Zealand Journal of Forestry, 22(2): 283-296. 
Cortina J., Vilagrosa A., Trubat R. 2013.The role of nutrients for improving seedling quality in drylands. New Forests, 44: 719-732. DOI: 10.1007/s11056-013-9379-3.

Davis A.S., Jacobs D.F. 2005. Quantifying root system quality of nursery seedlings and relationship to outplanting performance. New Forests, 30: 295-311.

Dickson A., Leaf A.L., Hosner J.F. 1960. Quality appraisal of white spruce and white pine seedling stock in nurseries. Forestry Chronicle, 36: 10-13. DOI: 10.5558/tfc36010-1.

Grossnickle S.C. 2012. Why seedlings survive: influence of plant attributes. New Forests, 43: 711738. DOI: $10.1007 / \mathrm{s} 11056-012-9336-6$.

Haase D.L. 2007. Morphological and physiological evaluations of seedling quality. W: National Proceedings: Forest and Conservation Nursery Associations - 2006. Red. L.E. Riley, R.K. Dumroese, T.D. Landis. Proceedings RMRS-P-50. Fort Collins, CO: U.S. Department of Agriculture, Forest Service, Rocky Mountain Research Station, 3-8.

Ivetić V., Grossnickle S., Škorić M. 2016. Forecasting the field performance of Austrian pine seedlings using morphological attributes. iForest, 10: 99-107. DOI 10.3832/ifor1722-009.

Khanal P.N., Dean T.J., Roberts S.D., Grebner D.L., Straka T.J. 2018. Explaining first-year seedling survival from quality distributions of bare-root seedlings and microsites in industrial plantations. Open Journal of Forestry, 8: 362-379. DOI: 10.4236/ojf.2018.83023.

Kozlowski T.T., Pallardy S.G. 2002. Acclimation and adaptive response of woody plants to environmental stress. The Botanical Review, 68: 270-334. DOI: 10.1663/0006-8101(2002)068[0270: AAAROW]2.0.CO;2.

Oliet J.A., Ortiz de Urbina E., Sánchez-Pinillos M., Tardío-Cerrillo G. 2019. Matching seedling size to planting conditions: interactive response with soil moisture. iForest, 12: 220-225. DOI: 10.3832/ifor2801-012.

PN-R-67025 1999. Materiał sadzeniowy - sadzonki drzew i krzewów do upraw leśnych i na plantacje. Polski Komitet Normalizacyjny. Wydawnictwo Normalizacyjne ALFA-WERO, Warszawa.

Thomson B.E. 1985. Seedling morphological evaluation. W: Proceedings: Evaluating seedling quality: principles, procedures and predictive abilities of major tests. Workshop held October 16-18, 1984. Red. M.L. Durvea. Forest Research Laboratory, Oregon State University, Corvallis, $59-71$.

TIBCO Software Inc. 2017. Statistica (data analysis software system), version 13. http://statistica.io.

\section{COMPARISON OF GROWTH PARAMETERS AND BREEDING USEFULNESS OF ONE-YEAR-OLD EUROPEAN BEECH (FAGUS SYLVATICA L.) SEEDLINGS}

\section{SUMMARY}

The study compares various parameters of European beech seedlings grown in controlled conditions depending on their quality class. The research material consisted of class I and II seedlings as well as classless seedlings, classified according to the criteria contained in the Polish standard PN-R-67025 (1999). The aim of the study was to show the differences 
between seedlings in individual classes, both for the growth traits and quality indicators determining their breeding usefulness. Each quality class was represented by 60 beech seedlings. Growth characteristics - height, length of the root system, and the root collar diameter - were measured and the dry weight of the seedling was determined, divided into parts, i.e. roots, shoots, and leaves. The shoot and roots portion of each seedling was scanned (Epson Photo V800 scanner) and the resulting electronic images were analysed using WinRhizo software (Regent Software Inc.). Using the measurement data, 3 synthetic indices were calculated to determine the seedling's cultivation suitability, i.e. its sturdiness quotient (SQ), shoot-root ratio (S/R), and Dickson quality index (DQI). All growth parameters as well as the features of the root system and shoots significantly distinguished seedlings in the quality classes, except for the length of the root system (tab. $1-2)$. The highest values of growth parameters and dry weight were found in the quality class I, and the lowest in classless seedlings. However, the breeding usefulness indicators did not confirm this rule. Although the Dickson quality index indicated that class I seedlings would be the most useful for planting in the forest plantation, no significant difference was obtained for the sturdiness quotient, and the best shoot-root ratio was found in classless seedlings (tab. 3). The share of beech seedlings in individual quality classes that did not meet the criterion of the maximum value of the sturdiness quotient (SQ $=65$ ), whereas the shoot-root ratio ( $\mathrm{S} / \mathrm{R} \leq 2: 1)$ did not differ significantly (fig. $1-2)$. The value of the Dickson quality index, determining the adaptability of the nursery material, indicated that for some classless seedlings it turned out to be higher than the average value of the index for class II seedlings and some seedlings classified to quality class I (fig. 3). The obtained results indicate that some classless seedlings may be suitable for planting in a forest plantation despite the failure to meet the minimum values of growth traits contained in the PN-R-67025 (1999) standard. Our research also suggests that in the assessment of the quality of planting material, as an element complementing the dimensional classification, we can include indicators of breeding suitability (SQ, S/R, DQI).

\section{KEYWORDS}

PN-R-67025 standard, WinRhizo, breeding suitability, sturdiness quotient, stem-root ratio, Dickson quality index 